Gut, 1987, 28, 1013-1021

\title{
Local IgA subclass alterations in ulcerative colitis and Crohn's disease of the colon
}

\author{
K KETT AND P BRANDTZAEG \\ From the Laboratory for Immunohistochemistry and Immunopathology (LIIPAT), Institute of Pathology, \\ University of Oslo, The National Hospital, Rikshospitalet, Oslo, Norway
}

SUMmaRY The subclass distribution of $\operatorname{IgA}$ producing cells was determined by paired immunofluorescence staining in colonic specimens from 10 patients with ulcerative colitis and eight with Crohn's disease. Compared with normal colonic mucosa, the percentage of IgA1 immunocytes showed a striking increase in both disorders. The proportion of mucosal IgA1 cells was significantly higher $(\mathrm{p}<0 \cdot 05)$ in ulcerative colitis (median, $71.2 \%)$ than in Crohn colitis (median, 56.9\%). Within each category of specimens no significant differences were noted between luminal and basal mucosal zones. The submucosal proportion of IgA1 cells was, however, significantly higher than the mucosal one in both ulcerative colitis (median, $89.1 \% ; \mathrm{p}<0.002$ ) and Crohn colitis (median, $91.8 \% ; \mathrm{p}<0.005)$. The mucosal shift towards IgA1 production paralleled the magnitude of the submucosal IgA1 cell proportion in individual tissue samples. Taken together with the previously reported dramatic increase of local IgG production (particularly observed in the submucosa and basal parts of the mucosa), our findings indicated that there is an influx and/or proliferation of $B$ cells representing systemic secondary immunity in the lesions of both diseases.

The numerical increase of mucosal $\operatorname{IgG}$ and $\operatorname{IgA}$ producing immunocytes in the order of 30 and two times, respectively, suggests that a pronounced and disproportionate local $\mathrm{B}$ cell response takes place in ulcerative colitis and Crohn's disease compared with the predominant normal colonic secretory $\operatorname{IgA}$ response.' Very little is known about the antibody specificities of the disease associated B cells. ${ }^{\prime}$ In ulcerative colitis there is relatively more local synthesis of the IgG1 subclass than in Crohn colitis; this has been shown both immunohistochemically? and by quantification of spontaneous IgG secretion from isolated intestinal lymphoid cells. ${ }^{3}$ Such a disparity between the two diseases is of pathogenetic interest. Both $\operatorname{IgG}$ and $\operatorname{IgA}$ antibodies may show subclass restriction to different antigens, ${ }^{+111}$ and further dissection of the local $\mathrm{B}$ cell responses is necessary to identify microbial components involved in inflammatory bowel disease.

The four IgG subclasses show functional differences which may be of biological importance."

Address for correspondence: Dr Kjell Kett. LIIPAT, Rikshospitalet, N-(0)27 Oslo 1, Norway.

Received for publication 5 December 1986
The two subclasses of $\operatorname{IgA}(\operatorname{IgA} 1 \text { and } \operatorname{IgA} 2)^{12-14}$ that can be distinguished immunologically are, however, apparently functionally identical except that $\operatorname{IgA} 1$ is susceptible to a variety of IgA-specific microbial proteases. ${ }^{1516}$ Moreover, the increased proportion of $\operatorname{IgA} 2$ in secretions compared with serum, ${ }^{17}$ and the relatively high frequency of IgA 2 producing immunocytes in the distal gut mucosa ${ }^{10}$ suggest that the two subclasses are subjected to different immunoregulatory mechanisms.

In this study we wanted to see if altered local immune regulation in inflammatory bowel disease is reflected by a shift in the mucosal distribution of $\operatorname{IgA}$ subclass-producing immunocytes.

\section{Methods}

PATIENTS AND MATERIALS

Ten patients with ulcerative colitis, four men and six women (median age, 39 years; range, 20 to 49 years) showing a median disease duration of three years (range, three weeks to 17 years) were included in the study along with eight patients with Crohn's disease of the colon, three men and five women (median age, 
28 years; range, 15 to 64 years) showing a median disease duration of eight years (range, two to 21 years). All patients had lesions throughout the entire length of the colon. Eight of those with ulcerative colitis and three with Crohn colitis were under treatment with corticosteroids. One Crohn patient was additionally treated with azathioprine and one received this drug only.

The final diagnosis was based on clinical features in combination with endoscopic findings or inspection of surgically resected material and on histopathological examination. Mucosal specimens were obtained at colonic resection (carried out because of severe disease activity or to avoid development of cancer in longstanding colitis) or by endoscopic suction biopsy at follow up examinations. All tissue specimens were from either the transverse or sigmoid colon. The mucosal IgG subclass response pattern in the same patients has been reported previously.?

\section{IMMUNOHISTOCHEMISTRY}

Tissue specimens were prepared as thin slices which were extracted in cold phosphate buffered isotonic saline to remove diffusible, extracellular proteins before ethanol fixation and paraffin embedding. ${ }^{19}$ Three serial sections were cut at $6 \mu \mathrm{m}$ from each tissue block; one was stained with haematoxylin and eosin for histologic examination and two were subjected to paired immunofluorescence staining (Fig. 1). The latter sections were first incubated for 20 hours at room temperature with murine monoclonal antibody to IgA1 (Clone 69-11.4; ascites, 1:5000) or IgA2 (Clone 16-512-H5; ascites, 1:10000) produced and tested for specificity as described elsewhere. ${ }^{20}$ The second incubation step included a mixture of rhodamine B sulphonyl chloride labelled rabbit antihuman $\operatorname{IgA}$ and fluorescein isothiocyanate labelled rabbit antimouse IgG. The characteristics and working concentrations of these conjugates have been described elsewhere. ${ }^{1 \times}$ They were applied for 20 hours at room temperature. To avoid fading of fluorescein emission the sections were, after the final wash, mounted in buffered ( $\mathrm{pH} 8$ ) polyvinyl alcohol containing paraphenylenediamine."

\section{MICROSCOPY AND CELL COUNTING}

Fluorescent cells with a distinctly stained cytoplasm were observed in a Leitz Ortoplan microscope equipped with X25 and X40 immersion objectives, an X10 ocular, and a Ploem-type vertical illuminator with interference filters for selective observation of fluorescein (green) and rhodamine (red) emission (Figs 2 and 3). Cell counting was done by the same observer throughout the study. The intra and interobserver reproducibility of this enumeration method has been reported previously. ${ }^{1 \times}$

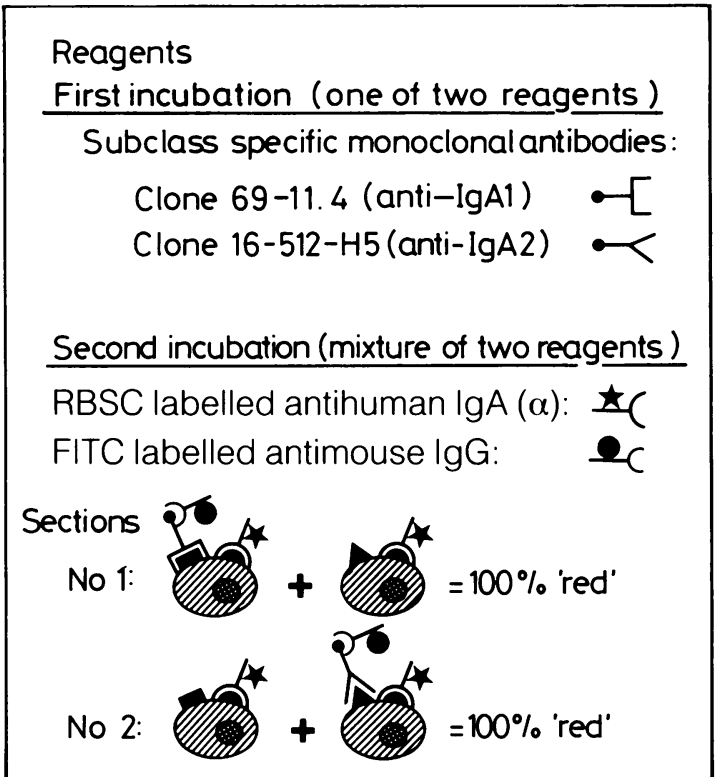

Fig. 1 Schematic illustration of paired immunofluorescence staining method and enumeration of $\operatorname{Ig} A$ subclass producing cells. The clone numbers refer to the codes of antibody suppliers. Rhodamine (RBSC) labelled antihuman $\operatorname{Ig} A$ was $\alpha$ chain specific ('red'); fluorescein (FITC) labelled antimouse $\lg G$ was used to label indirectly the two monoclonal antibodies.

To obtain an indication of disease associated subclass alterations, our enumerations were expressed as immunocyte ratios for individual specimens (which thereby all had the same statistical weight). The counts were based on mucosal areas with dense infiltrates of Ig-producing immunocytes which usually extended into the submucosa, especially in Crohn colitis.

Areas with ulcers and fissures were avoided because of persistent background staining and relative scarcity of $\operatorname{IgA}$ producing cells. While IgG producing cells were located mainly in such areas and in the deeper layer of the mucosa (and also in the submucosa)"- IgA immunocytes were abundantly present throughout the mucosa and particularly in the luminal part.

In all but one of the paired adjacent sections of each disease category, the lamina propria could be divided into a luminal and a basal zone in which the IgA cells were counted separately. The submucosa was lacking in three specimens of ulcerative colitis and in one of Crohn colitis; for the other samples IgA cells were counted separately also in the submucosa.

For each tissue specimens an average of 605 red (class specific) cells (range, 136 to 1474) were examined for concomitant green (subclass specific) 

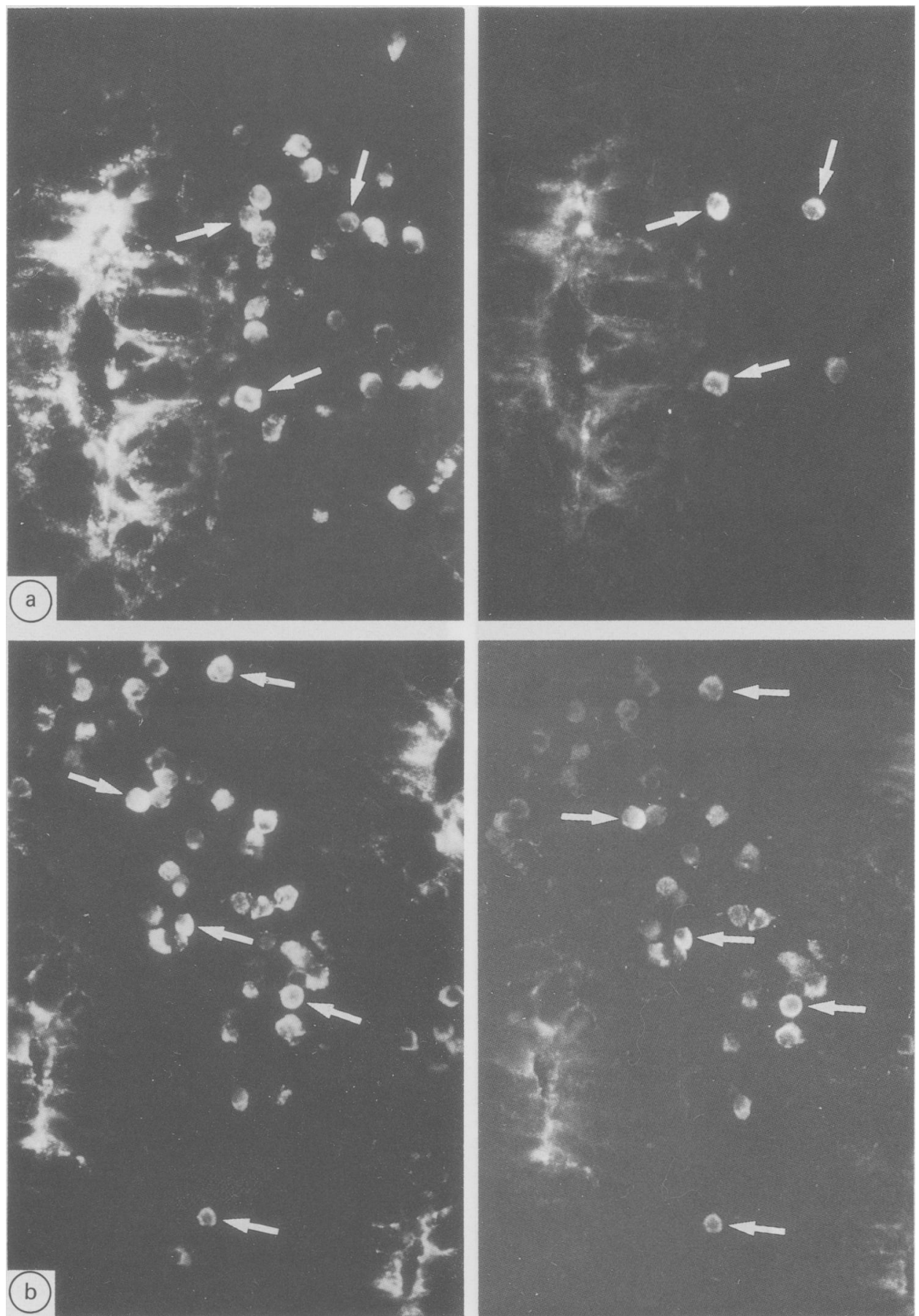

Fig. 2 (a) Paired immunofluorescence staining for IgA (left panel, rhodamine) and IgAl subclass (right panel, fluorescein) in the same field from section of normal colonic mucosa. (b), Similar staining for $\lg A$ (left) and IgA2 (right) in adjacent section. Note relatively large proportion of IgA2-producing cells and uptake of both subclasses in crypt epithelium. Examples of identical cells in paired pictures are indicated by arrows. 

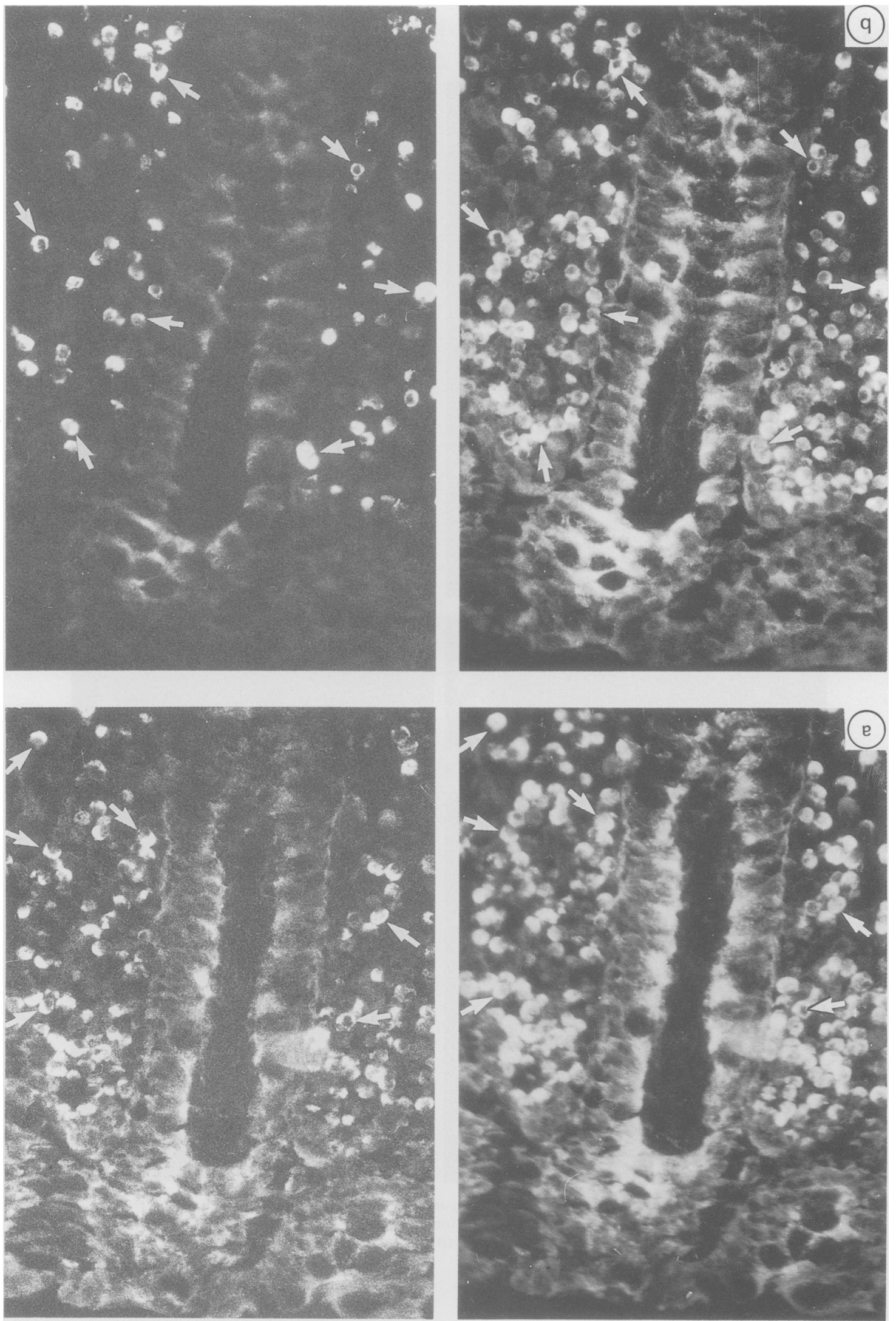

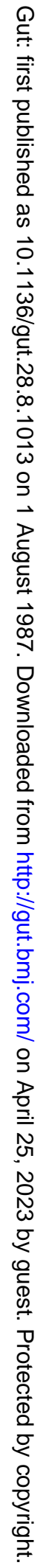


fluorescence. The proportion of subclass positive immunocytes was then calculated in relation to the total number of $\operatorname{IgA}$ producing cells present in the evaluated area of each section (Fig. 1). The sum of the IgA1 and IgA2 percentages in the two adjacent sections was usually close to $100 \%$ (range, $96 \%$ $107 \%$ ) and so was also the sum of the subclass medians calculated for each disease category (Fig. 4).

STATISTICAL ANALYSIS

Differences between proportions of the two subclasses were calculated by Wilcoxon's two-tailed test for unpaired samples. The relations between mucosal and submucosal IgA1 percentages were determined by analysis of covariance.

\section{Results}

Figure 4 shows the percentage distribution of mucosal and submucosal IgA1 and IgA2 cells in the two disorders as compared with that previously observed in normal colonic mucosa. ${ }^{18} \mathrm{~A}$ striking and highly significant increase of the mucosal $\operatorname{IgA} 1$ percentage was found both in ulcerative colitis $(\mathrm{p}<0 \cdot 02)$ and in Crohn colitis $(\mathrm{p}<0 \cdot 015)$. Moreover, the mucosal IgA1 cell proportion was significantly higher $(\mathrm{p}<0 \cdot 05)$ in ulcerative colitis (median, $71.2 \%$ ) than in Crohn colitis (median, $56.9 \%$ ). Conversely the $\operatorname{IgA} 2$ cell proportion was significantly higher $(p<0.05)$ in the latter (median, $43.1 \%)$ than in the former (median, $31.5 \%$ ) disorder.

Neither disease showed significant differences between luminal and basal mucosal zones. The proportion of IgA1 cells in the submucosa, however, was in both ulcerative colitis and Crohn colitis significantly higher $(p<0.002$ and $p<0.005$, respectively) than in the mucosa. In Crohn colitis the submucosal IgA1 percentage was $91.8 \%$ and in ulcerative colitis $89 \cdot 1 \%$. In individual tissue specimens a strikingly parallel contribution of $\operatorname{IgA} 1$ producing cells was observed in the mucosa and submucosa (Fig. 5).

\section{Discussion}

This is the first immunohistochemical study on the subclass distribution of $\operatorname{IgA}$ producing immunocytes in colonic specimens from patients with ulcerative colitis and Crohn's disease of the colon. We found in both disorders a marked increase of the mucosal IgA1 to IgA2 cell ratio compared with the immunocyte distribution in normal colonic mucosa. ${ }^{18}$ This shift to local IgA1 production was significantly larger in ulcerative than in Crohn colitis.

Immunohistochemical studies have unequivocally shown a striking predominance $(80-90 \%)$ of $\operatorname{IgA}$ containing immunocytes in normal intestinal mucosa. ${ }^{23.25}$ These cells produce mainly dimers (or larger polymers) as evidenced by concurrent staining for $\mathbf{J}$ chain along with cytoplasmic affinity for secretory component (SC) in vitro 2627 and by spontaneous release in cultures. ${ }^{2824}$ Local production of polymeric $\operatorname{IgA}(\mathrm{pIgA})$ is the basis for secretory immunity because epithelial SC acts as a pIgA receptor, thereby facilitating external translocation of secretory IgA. ${ }^{311}$ In a recent study of the normal intestinal IgA subclass distribution, however, we found a striking heterogeneity in that $\operatorname{IgA} 1$ cells dominated $(77 \%)$ proximally whereas large bowel mucosa contained mainly $(59 \%)$ IgA2 cells. ${ }^{18}$ Although both pIgA subclasses can bind to SC,$^{31}$ this observation indicated regional differences in the regulation of intestinal immunity.

Published data show large discrepancies with regard to the mucosal distribution of Ig-producing cells in ulcerative colitis and Crohn's disease. ${ }^{22} 32.35$ Various methodological problems may explain these differences as discussed elsewhere. ${ }^{25}$ Studies based on cultures of intestinal lymphoid cells have confirmed our original immunohistochemical findings of a strikingly increased local IgG production in both disorders. ${ }^{335-38}$ Conflicting culture results have been published with regard to $\operatorname{IgA} . .^{29}{ }^{36-38}$ Spontaneous $\operatorname{IgA}$ secretion in vitro is difficult to interpret in quantitative terms, however, because of uncontrolled dilutional effects caused by a disproportionate increase of the $\operatorname{IgA}$ cell fraction.

Our quantitative immunohistochemical studies of intestinal immunocytes have been based on a 'tissue unit' which represents a $6 \mu \mathrm{m}$ thick and $500 \mu \mathrm{m}$ wide block of the mucosa from the muscularis mucosae to the gut lumen.22 On this basis we reported that the total number of IgA producing cells showed approximately a two fold increase in both ulcerative and Crohn colitis. ${ }^{34}$ In the present study we found that this increase was mainly explained by $\operatorname{IgA} 1$ producing cells. Our observation is in keeping with recently published results based on spontaneous IgA release from dispersed lymphoid cells obtained from

Fig. 3 (a) Paired immunofluorescence staining for IgA (left panel, rhodamine) and IgA I subclass (right panel, fluorescein) in the same field from section of colonic mucosa from patient with Crohn's disease. (b) Similar staining for IgA (left) and IgA2 (right) in adjacent section. Note high immunocyte density and predominance of IgAI producing cells; the latter subclass also predominates in crypt and surface epithelium (gut lumen at the top). Examples of identical cells in paired pictures are indicated byarrows. 


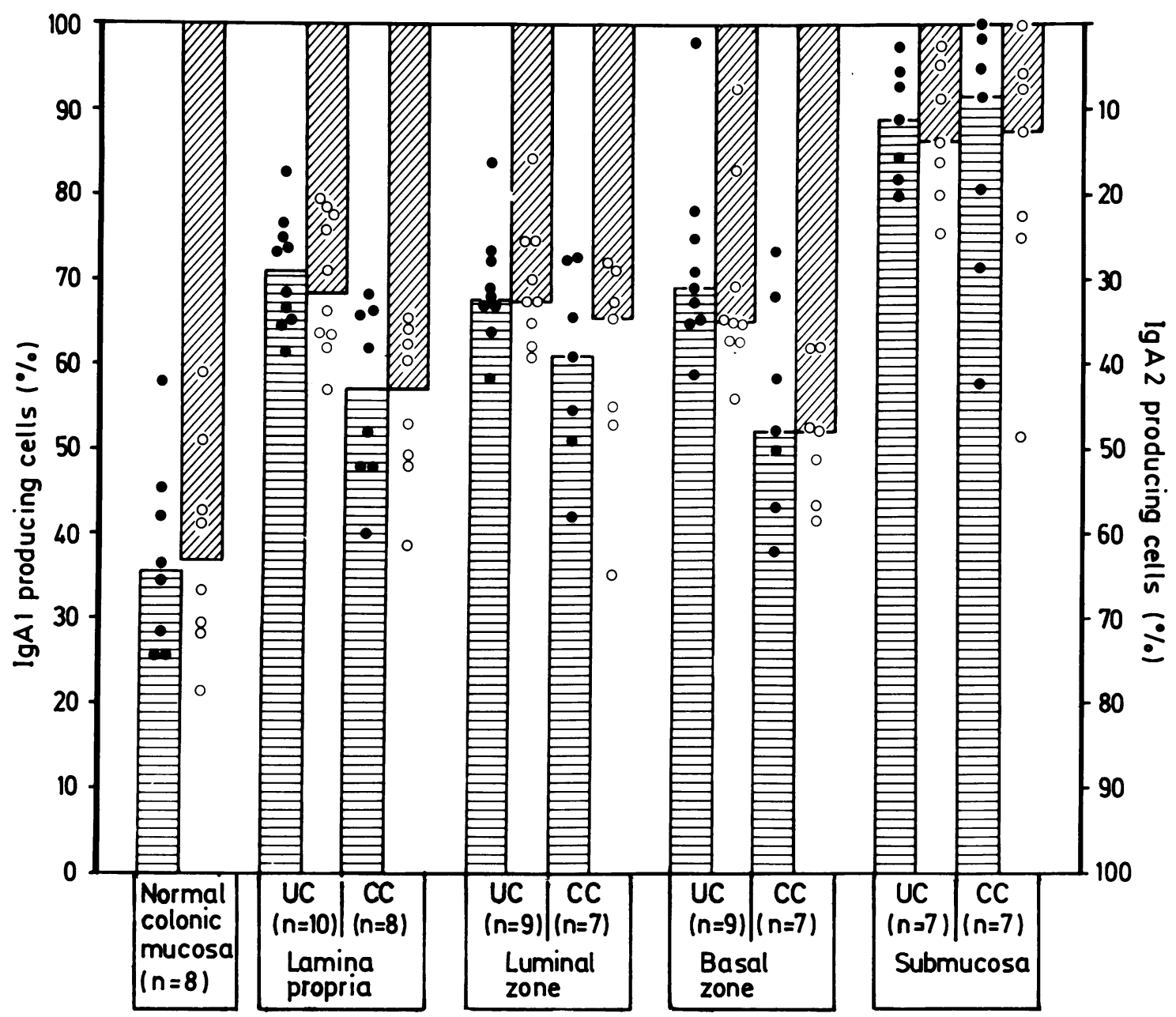

Fig. 4 Scatter diagram of percentage distribution of $\operatorname{Ig} A I(\bigcirc)$ and $\operatorname{Ig} A 2(\bigcirc)$ cells in normal colonic mucosa' ${ }^{\prime \prime}$ and in diseased colonic lamina propria (total mucosa and luminal and basal zones) and submucosa from patients with ulcerative colitis (UC) and Crohn's disease of the colon $(C C)$. The median percentages for $I g A I$ and $I g A 2$ cells are indicated by differently hatched columns.

the gut wall down to the musculature. ${ }^{29}$ It is difficult to know what extent submucosal cells were included in the cultures, and the results were indistinguishable for the two diseases. Our findings showed that the percentage of $\operatorname{IgA} 1$ cells in the mucosa was significantly related to that in the submucosa which, however, was always much higher than the former. These results paralleled our observations of a shift towards local $\operatorname{IgA}$ monomer production in inflammatory bowel disease as determined immunohistochemically by staining for $\mathrm{J}$ chain expression and cytoplasmic SC affinity. ${ }^{20}$ Again, these findings were in keeping with observations on dispersed cells from the lesions. $.^{29}, 39$

Altogether, the markedly increased number of $\mathrm{J}$ chain negative $\operatorname{IgG}$ producing mucosal cells ${ }^{127}$ and the shift towards local production of monomeric $\operatorname{Ig} \mathrm{A}^{27}$ and the $\operatorname{Ig} \mathrm{A} 1$ subclass, show that the secretory immune system is partially replaced by B cells belonging to mature memory clones compatible with a systemic type of immunity. These cells may originate directly from the circulation and migrate from the basal parts of the mucosa into the lamina propria and the submucosa. The submucosal infiltrate contains Ig-producing cells which in terms of class and subclass proportions match those present in bone marrow, ${ }^{+1+1}$ peripheral lymph nodes and tonsils. ${ }^{+1+2}$ Alternatively, IgA1 cells may develop within the tissue lesions as a result of heavy chain switching from the abundant precursors of the IgG1 


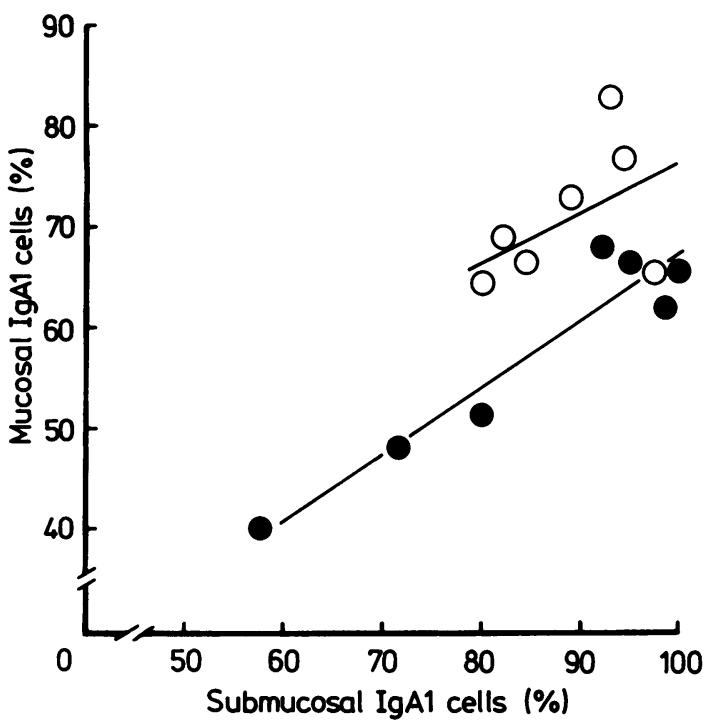

Fig. 5. Scatter diagram with regression lines of $\mathrm{IgAl}$ immunocyte percentage in mucosa on that of submucosa in patients with ulcerative colitis $(U C, o)$ versus Crohn's disease of the colon (CC, O). Analysis of covariance did not reveal any established difference between the series-specific deviations from regression or between the corresponding regression coefficients. The regression lines could therefore be assumed to be parallel, with a common regression coefficient of $+0.625 \%$ increase in mucosal IgAl per unit increase in submucosal content $(p<0 \cdot 001)$. The $95 \%$ confidence limits of the common slope were estimated at $+0 \cdot 352$ and $+0 \cdot 898$. The adjusted mean of the UC series $(66 \cdot 3 \%)$ was above that of the CC group $(62 \cdot 2 \% ; p<0.005)$.

isotype, as recently reported for human myeloma cells. ${ }^{3+4}$

An additional possibility is that the disease associated immunocytes originate in solitary lymphoid nodules within the mucosa. We have recently found that there is an IgG-dominated population of plasma cells with repressed $\mathbf{J}$ chain expression associated with these structures and with the Peyer's patches. ${ }^{45}$ These lymphoid sites are collectively considered responsible for generation of the precursor cells that 'home' to secretory sites and end up mainly as J chain positive pIgA producers. ${ }^{\text {th }}$ Retention and terminal maturation to plasma cells in situ, therefore, seem to involve only relatively mature B cell clones. It is possible that this precursor fraction is dramatically increased in the diseased mucosa because of massive exposure to luminal antigens and mitogens. The shift to mucosal IgA1 production was more pronounced in ulcerative colitis than in Crohn's disease, which might reflect better preservation of mucosal integrity in the latter (areas of overt ulceration were avoided).

It is at present unknown whether the underlying immunoregulatory alterations are primary or secondary events in the pathogenesis of inflammatory bowel disease. A shift towards local production of monomeric IgA does not support secretory immunity, and there is some indication that secretory antibodies to lipotheichoic acid and bacterial lipopolysaccharides are preferentially carried by $\operatorname{IgA} 2 .^{69}$ In addition, $\operatorname{IgA} 1$ is susceptible to $\operatorname{IgA}$ specific proteases which may occur in faeces. ${ }^{47}$

Nevertheless, it is questionable whether the observed alterations in local IgA production will compromise secretory immunity. In patients with Crohn's disease circulating IgA shows in fact some increase of the pIgA fraction and a tendency to a raised $\operatorname{IgA} 2$ proportion, ${ }^{+8}$ probably as a reflection of an intensified secretory immune response in the distal bowel mucosa. The concurrent pronounced local IgG production may be of much greater pathogenic significance as discussed elsewhere.' This possibility is supported by the recently reported differences between ulcerative colitis and Crohn colitis as to the subclass distribution of mucosal IgG immunocytes. ${ }^{2}$

Kjell Kett is a senior lecturer at the Department of Medicine, Central Hospital of Akershus, University of Oslo. The authors thank the staff of the Laboratory for Gastroenterology Medical Department A, and the Surgical Department B, Rikshospitalet, for tissue specimens and Drs J Radl and J J Haaijman, Institute of Experimental Gerontologi, Rijswiik, The Netherlands, for the gift of monoclonal antibodies. We are indebted to Prof Per Wetteland for help with statistical analysis. This work was supported by the Norwegian Cancer Society, The Norwegian Research Council for Science and the Humanities, and Anders Jahre's Foundation.

\section{References}

1 Brandtzaeg P, Valnes K, Scott H, Rognum TO, Bjerke $\mathrm{K}$, Baklien $\mathrm{K}$. The human gastrointestinal secretory immune system in health and disease. Scand J Gastroenterol 1985; 20: suppl 114: 17-38.

2 Kett K, Rognum TO, Brandtzaeg P. Mucosal subclass distribution of IgG-producing cells is different in ulcerative colitis and Crohn's disease of the colon. Gastroenterology 1987; (in press).

3 Scott MG, Nahm MH, Macke K, Nash GS, Bertovich MJ, MacDermott RP. Spontaneous secretion of IgG subclasses by intestinal mononuclear cells: differences between ulcerative colitis, Crohn's disease, and controls. Clin Exp Immunol 1986; 66: 209-15.

4 Shakib F, Stanworth DR. Human IgG subclass in health and disease. Ricerca Clin Lab 1980; 10: 561-80.

5 Hammarström L, Granström M, Oxelius V, Persson AA, Smith CIE. IgG subclass distribution of antibodies against $\mathrm{S}$. aureus teichoic acid and -toxin in normal and immunodeficient donors. Clin Exp Immunol 1984; 55: 593-601.

6 Russel MW, Hammond D, Radl J, Haaijman JJ, 
Mestecky J. Secretory $\operatorname{IgA1}$ and $\operatorname{IgA} 2$ responses to environmental antigens. Protides Biol Fluids 1984; 32: 77-80.

7 Russel MW, Mestecky J, Julian BA, Galla TH. IgAassociated renal diseases: antibodies to environmental antigens in sera and deposition of immunoglobulins and antigens in glomeruli. J Clin Immunol 1986; 6: 74-87.

8 Brown TA, Mestecky J. Immunoglobulin A subclass distribution of naturally occurring salivary antibodies to microbial antigens. Infect Immun 1985; 49: 459-62.

9 Brown TA, Murphy BR, Radl J, Haaijman JJ, Mestecky J. Subclass distribution and molecular form of immunoglobulin A haemagglutinin antibodies in sera and nasal secretions after experimental secondary infection with influenza $A$ virus in humans. J Clin Microbiol 1985; 22: 259-64.

10 Persson MAA, Ekwall E, Hammarström L, Lindberg AA, Smith CIE. Immunoglobulin G (IgG) and IgA subclass pattern to human antibodies to Shigella flexneri and Salmonella serogroup $B$ and D lipopolysaccharide $\mathrm{O}$ antigens. Infect Immun 1986; 3: 834-9.

11 Shahib F, Stansworth DR. Human IgG subclass in health and disease. Ricerca Clin Lab 1980; 10: 463-79.

12 Feinstein D, Franklin EC. Two antigenically distinguishable subclasses of human A myeloma proteins differing in their heavy chains. Nature 1966; 212: 1496-98.

13 Kunkel HG, Prendergast RA. Subgroups of A immunoglobulins. Proc Soc Exp Biol Med 1966; 122: 910-13.

14 Vaerman JP, Heremans JF. Subclasses of human immunoglobulin A based on differences in the alpha polypeptide chains. Science 1966: 153: 647-49.

15 Plaut AG. The IgAl proteases of pathogenic bacteria. Ann Rev Microbiol 1983; 37: 603-22.

16 Kilian M, Thomsen B, Petersen TE, Bleeg HS. Occurrence and nature of bacterial IgA proteases. Ann NY Acad Sci 1983; 409: 612-623.

17 Delacroix DL, Dive C, Rambaud JC, Vaerman JP. IgA subclasses in various secretions and in serum. Immuno$\log y 1982 ; 47$ : 383-85.

18 Kett K, Brandtzaeg P, Radl J, Haaijman JJ. Different subclass distribution of IgA-producing cells in human lymphoid organs and various secretory tissues. $J$ Immunol 1986; 136: 3651-5.

19 Brandtzaeg P. Mucosal and glandular distribution of immunoglobulin components. Immunohistochemistry with a cold ethanol fixation technique. Immunology 1974; 26: 1101-13.

20 Valentijn RM, Radl J, Haaijman JJ, et al. Circulating and mesengial secretory component-binding $\operatorname{IgA}-1$ in primary IgA nephropathy. Kidney Int 1984; 26: 760-66.

21 Valnes K, Brandtzaeg P. Reterdation of immunofluorescence fading during microscopy. $J$ Histochem Cytochem 1985; 33: 755-61.

22 Brandtzaeg P, Baklien K, Fausa D, Hoel PS. Immunohistochemical characterization of local immunoglobulin formation in ulcerative colitis. Gastroenterology 1974; 66: 1123-36.

23 Crabbé PA, Carbonara AO, Heremans JF. The normal human intestinal mucosa as a major source of plasma cells containing A-immunoglobulin. Lab Invest 1965; 14: $235-48$.
24 Rubin W, Fauci AS, Marvin SF, et al. Immunofluorescent studies in adult celiac disease. J Clin Invest 1965 ; 44: 475-85.

25 Brandtzaeg P, Baklien K. Immunohistochemical studies of the formation and epithelial transport of immunoglobulins in normal and diseased human intestinal mucosa. Scand J Gastroenterol 1976; 11: suppl 36: 1-45.

26 Brandtzaeg P. Immunohistochemical characterization of intracellular $\mathrm{J}$-chain and binding site for secretory component (SC) in human immunoglobulin (Ig)producing cells. Mol Immunol 1983; 20: 941-66.

27 Brandtzaeg P, Korsrud FR. Significance of different J chain profiles in human tissues: generation of $\operatorname{IgA}$ and IgM with binding site for secretory component is related to the $J$ chain expressing capacity of the total local immunocyte population, including IgG and $\operatorname{IgD}$ producing cells, and depends on the clinical state of the tissue. Clin Exp Immunol 1984; 58: 709-18.

28 Kutteh WH, Prince SJ, Mestecky J. Tissue origins of human polymeric and monomeric IgA. J Immunol 1982; 128: 990-5.

29 MacDermott RP, Nash GS, Bertovich MJ, et al. Altered patterns of secretion of monomeric $\operatorname{IgA}$ and $\operatorname{IgA}$ subclass 1 by intestinal mononuclear cells in inflammatory bowel disease. Gastroenterology 1986; 91: 379-85.

30 Brandtzaeg P. Role of chain and secretory component in receptor-mediated glandular and hepatic transport of immunoglobulins in man. Scand J Immunol 1985; 22: 111-46.

31 Brandtzaeg P. Complex formation between secretory component and human immunoglobulins related to their content of J chain. Scand J Immunol 1976; 5: 411-19.

32 Soltoft J, Binder V, Gudmund-Hoyer E. Intestinal immunoglobulins in ulcerative colitis. Scand J Gastroenterol 1973; 8: 293-300.

33 Skinner JM, Whitehead R. The plasma cells in inflammatory disease of the colon: a quantitative study. J Clin Pathol 1974; 27: 643-6.

34 Baklien K, Brandtzaeg P. Comparative mapping of the local distribution of immunoglobulin-containing cells in ulcerative colitis and Crohn's disease of the colon. Clin Exp Immunol 1975; 22: 197-209.

35 Fiorilli M, Luzi G, Aiuti F. Immunoglobulin production by the rectal mucosa in subjects with ulcerative colitis. Rendic Gastroenterol 1975; 7: 1-4.

36 McClelland DBL, Shearman DJC, Lai a Fat RFM, van Furth $\mathrm{R}$. In vitro synthesis of immunoglobulins, secretory component, complement and lysozyme by human gastrointestinal tissues. Clin Exp Immunol 1976; 23: 20-7.

37 Bookman MA, Bull DM. Characteristics of isolated intestinal mucosal lymphoid cells in inflammatory bowel disease. Gastroenterology 1979; 77: 503-10.

38 Danis VA, Harries AD, Heatley RV. In vitro immunoglobulin secretion by normal human gastrointestinal mucosal tissues, and alterations in patients with inflammatory bowel disease. Clin Exp Immunol 1984; 56: 159-66.

39 MacDermott RP, Beale MG, Alley CD, Nash GS, Bertovich MJ, Bragdon MJ. Synthesis and secretion of $\operatorname{IgA}, \operatorname{IgM}$, and IgG by peripheral blood mononuclear 
cells in human disease states, by isolated human intestinal mononuclear cells, and by human bone marrow mononuclear cells from ribs. Ann NY Acad Sci 1983; 409: 498-509.

40 Turesson I. Distribution of immunoglobulin-containing cells in human bone marrow and lymphoid tissues. Acta Med Scand 1976; 199: 293-304.

41 Crago SS, Kutteh WH, Moro I, et al. Distribution of $\operatorname{IgA} 1-, \operatorname{IgA} 2-$, and $\mathrm{J}$ chain-containing cells in human tissues. J Immunol 1984; 132: 16-18.

42 Brandtzaeg P, Surjan L, Berdal P. Immunoglobulin systems of human tonsils. Clin Exp Immunol 1978; 31: 367-81.

43 Hammarström L, Mellstedt $\mathrm{H}$, Persson MAA, Smith CIE, Ahre A. IgA subclass distribution in paraproteinemias: suggestion of an IgG-IgA subclass switch pattern. Acta Pathol Microbiol Immunol Scand Sect C 1984; 92: 207-11.

44 Takahashi M, Tsukada T, Kojima M, et al. Immuno- globulin class switch from IgG to $\operatorname{IgA}$ in a patient with smoldering multiple myeloma. Blood 1986; 67: 1710-13.

45 Bjerke $\mathrm{K}$, Brandtzaeg $\mathrm{P}$. Immunoglobulin- and $\mathrm{J}$ chainproducing cells associated with lymphoid follicles in the human appendix, colon and ileum, including Peyer's patches. Clin Exp Immunol 1986; 64: 432-41.

46 Brandtzaeg P. Research in gastrointestinal immunology. State of the art. Scand J Gastroenterol 1985; 20: suppl 114: 137-56.

47 Metha SK, Plaut AG, Calvanico NJ, Tomasi TB. Human immunoglobulin $\mathrm{A}$ : production of an $\mathrm{Fc}$ fragment by an enteric microbial proteolytic enzyme. $J$ Immunol 1973; 111: 1274-76.

48 Delacroix DL, Elkon KB, Geubel AP, Hodgson HF, Dive C, Vaerman JP. Changes in size, subclass, and metabolic properties of serum immunoglobulin $\mathrm{A}$ in liver diseases and in other diseases with high serum immunoglobulin A. J Clin Invest 1983; 71: 358-67. 